\title{
Você não fala sobre o Clube da Luta: diálogos entre cinema e psicanálise
}

You don't talk about Fight Club: dialogues on cinema and psychoanalysis

Nadie habla sobre el Club de la Lucha: diálogo entre psicoanálisis y cine

\author{
Gustavo Caetano de Mattos Mano* \\ Amadeu de Oliveira Weinmann ${ }^{*}$
}

\begin{abstract}
Resumo
Neste ensaio, utilizamos o filme Clube da Luta (1999), dirigido por David Fincher, para explorar as interseçôes entre cinema e psicanálise. Buscamos entender o que leva Clube da Luta a fazer marca em nossa cultura, trabalhando com a hipótese de que o filme enuncia algo da adolescência, que desponta como um dos traços mais proeminentes dos modos de subjetivação contemporâneos. A adolescência, tomada como um tempo constituinte do sujeito, se expressa pelo ensaio de uma posição autoral que, entretanto, acaba muitas vezes indefinidamente postergada pela própria configuração da cultura. Nesse sentido, interrogamos a dificuldade de produzir uma marca simbólica singular diante do Outro como mola da angústia que atravessa a narrativa de Clube da Luta e aprisiona os sujeitos contemporâneos à condição de adolescentes.
\end{abstract}

Palavras-chave: Psicanálise. Cinema. Clube da Luta. Adolescência.

\begin{abstract}
In the present essay, the authors use David Fincher's Fight Club (1999) to explore the intertwining between cinema and psychoanalysis, trying to understand what makes this movie leave a mark on our culture. Our hypothesis is that Fight Club manages to enunciate something about adolescence, which stands out as one of the most expressive traits of contemporary subjectivation. Adolescence, understood as a structuring time, is characterized by the exercise of an authorial position that is however postponed indefinitely as an effect of the very culture conformation. As so, we examine the difficulties of inscribing a unique mark as the spark for the anguish that flows throught Fight Club's story and traps the contemporary subjects in the adolescent status.
\end{abstract}

Keywords: Psychoanalysis. Cinema. Fight Club. Adolescence.

\footnotetext{
Mestre em Psicologia Social e Institucional pela UFRGS, especialista em Atendimento Clínico pela Clínica de Atendimento Psicológico da UFRGS, pesquisador no Laboratório de Pesquisa em Psicanálise, Arte e Política (Lappap), psicólogo.

** Professor do Departamento de Psicanálise e Psicopatologia do Instituto de Psicologia da UFRGS.
} 


\section{Resumen}

En este ensayo, hemos utilizado la película Club de la Lucha (1999) dirigida por David Fincher, para explorar las intersecciones entre cine y psicoanálisis. Pretendemos entender lo que hace que Club de la Lucha marque nuestra cultura, trabajando con la hipótesis de que la película enuncia algo de la adolescencia, que despunta como uno de los rasgos más preeminentes de los modos de subjetivación contemporáneos. La adolescencia, comprendida como un tiempo constituyente del sujeto, se expresa por el ensayo de una posición autoral que, sin embargo, muchas veces acaba indefinidamente postergada por la propia configuración de la cultura. En ese sentido, interrogamos la dificultad de producir una marca simbólica singular ante el Otro como muelle de la angustia que atraviesa la narrativa del Club de la Lucha y aprisiona a los sujetos contemporáneos en la condición de adolescentes.

Palabras clave: Psicoanálisis. Cine. Club de la Lucha. Adolescencia.

\section{Introdução}

m 2012, o filme Clube da Luta completou 13 anos, o que, em uma cultura voltada ao consumo inclemente de novidades, eleva-o ao estatuto de "clássico". Baseado no livro homônimo de Chuck Palahniuk, lançado em 1996 (três anos antes do filme, portanto), Clube da Luta inspirou centenas de psicólogos e psicanalistas a tecerem comentários articulando a película às suas teorias. Alguns escritos dedicaram-se a estabelecer hipóteses diagnósticas para as personagens; outros, a correlacionar o lançamento da película ao crescimento de episódios de violência; e uns tantos, sob premissas diversas, empenharam-se fundamentalmente em fazer retornar ao papel, sob palavras próprias entrecortadas por termos do léxico da psicologia, as formidáveis cenas dirigidas por David Fincher.

Partimos, em nosso ensaio, com uma meta mais pretensiosa: tentar entender o que leva Clube da Luta a fazer marca em nossa cultura. Não se trata de uma resenha crítica, ainda que esta fosse merecida, tendo em vista o relançamento do romance de Palahniuk pela Editora LeYa, após muito tempo longe das prateleiras do Brasil. Tampouco será um exercício de psicanálise aplicada, no qual são introduzidos recortes com o propósito de ilustrar os conceitos mais favoráveis. Neste escrito, a psicanálise tomará o lugar de um interlocutor privilegiado, capaz de simultaneamente interrogar e ser interrogada pela obra a qual se dedica. Esta, aliás, é a função que entendemos caber à prática analítica: 
questionar a subjetividade, de maneira a poder abrir caminhos inéditos de construção de si. Este ensaio parte, portanto, da hipótese de que Clube da Luta toca, sutil, porém intensamente, em um dos traços mais representativos da subjetivação contemporânea: a adolescência.

Enéas de Souza assinala que o roteiro de um filme constitui um "esqueleto que adquire carne, vida, beleza e arte somente quando posto em imagem" (Souza, 2011, p. 15). A análise fílmica ultrapassa a exploração do roteiro, cuja função é ordenar a cronologia da narrativa, dar-lhe uma estrutura, estabelecer de que forma a história será contada. $\mathrm{O}$ argumento, o storyboard e o script formam o tutano desse esqueleto, ainda que seja necessário o revestimento das imagens visuais e sonoras para que possamos ter um filme propriamente dito. Entretanto não podemos deixar de tomá-los em consideração na elaboração de uma leitura crítica sobre a produção, em especial quando se trata de uma transposição à tela de uma peça literária, como vem a ser o caso de Clube da Luta. Em nosso trabalho, não deixamos de consultar também o texto de Palahniuk, que, embora pertença a uma trama discursiva distinta (a literatura, e não o cinema), opera em nosso ensaio como substrato textual, da mesma forma que Fincher serviu-se dele para a produção de sua obra. Recusar o acesso ao livro ou ignorar sua existência parece-nos uma omissão descabida, visto que as fidelidades e os contrastes entre filme e livro deixam a descampado as opções do diretor na construção de sua narrativa: os rumos que a história poderia ter tomado, mas não tomou; as cenas e informaçôes omitidas, assim como os enxertos e os improvisos; enfim, as censuras, as condensaçóes e os deslocamentos produzidos na passagem de uma linguagem a outra (e que, se não abdicamos de nosso compromisso clínico, não podem deixar de nos interessar).

Caberia oferecer uma breve retomada do enredo de Clube da Luta: ao retornar de mais uma viagem, o narrador1 (corpo e voz de Edward Norton), um insone funcionário de uma megacorporação automotiva e frequentador de grupos de ajuda mútua para doenças graves das quais ele próprio não padece, descobre que seu confortável apartamento foi arrasado em uma explosão. Decide, então, recorrer ao peculiar Tyler Durden2 (interpretado por Brad Pitt) e pedir-lhe abrigo. Tyler consente, com uma condição: que o narrador bata nele o mais forte que puder. Esse

\footnotetext{
Por razões que serão discutidas ao longo do texto, optamos por respeitar a decisão estilística original e designar o narrador apenas como "narrador", apesar dos eventuais prejuízos que essa opção possa trazer à clareza do artigo. A questão da nomeação será devidamente explorada posteriormente.

Como em qualquer adaptação, o filme guarda algumas diferenças em relação ao livro; por exemplo, o primeiro encontro entre Tyler e o narrador, no livro, ocorre em uma praia; no filme, se dá no interior de um avião. Da mesma forma, na versão fílmica, ao descobrir seu apartamento em chamas, o narrador cogita inicialmente telefonar para Marla, mas desiste; no livro, Tyler é imediatamente contatado. Em nosso trabalho, assinalaremos somente os casos onde as distinçóes interessarem ao debate; uma lista mais ampla poderá ser encontrada em http://thatwasnotinthebook.com/diff/fightclub.
} 
é o início dos clubes da luta, onde homens desconhecidos reúnem-se a cada noite para trocar socos. E também da companhia de sabão da Paper Street. E do Projeto Destruição. ${ }^{3}$ E da cena inicial, na qual Tyler enfia uma arma na boca do narrador, dentro de um prédio prestes a ser dinamitado. E tudo isso tem a ver com Marla Singer (vivida na tela por Helena Bonhan Carter).

Concordamos que, para o leitor desprevenido, talvez essa sinopse mostre-se difícil de acompanhar. Mas assim é o ritmo impresso na trama de Palahniuk e transposto às telas com maestria por Fincher: um roteiro acelerado, de cortes secos, cenas visualmente sofisticadas, diálogos curtos e fortes, eventualmente intercalados por digressōes complexas; por trás disso, um narrador pouco confiável tentando ordenar aquilo que lhe ocorre. ${ }^{4} \mathrm{Um}$ estilo ao qual esse ensaio tenta honrar.

\section{A ficção e sua interpretação}

Uma revisão da literatura constatará que um bom número de escritos propôs-se a tecer hipóteses sobre a patologia do narrador (caso ainda seja uma surpresa para o leitor, é revelado no final do filme que ele e Tyler Durden são a mesma pessoa). Os manuais diagnósticos receberam incursões de toda a sorte, munindo autores de categorias nosográficas variadas que foram disparadas, com maior ou menor rigor, contra as personagens. Arós e Vaisberg (2009), que denominam o narrador de Jack, trabalham com o conceito de falso self, concluindo por um quadro de psicose clínica; na interpretação de Minerbo et al. (2006, p. 154), por sua vez, "Tyler representa o ideal de ego de Jack, com o qual se funde na psicose, tornando-se seu próprio ideal”. Retomamos, pois, a opinião de Lacan, precisamente recordada por Enéas de Souza (2011), em $O$ divã e a tela: não se psicanalisa personagens. No mesmo passo, Fantini (2009) traz uma posição mais profícua: embora assinale a psicose da personagem interpretada por Brad Pitt, prefere conferir ênfase ao declínio social da eficácia simbólica do Nome do Pai. Nossa análise, todavia, enveredará por outro caminho; a saber, a articulação entre a experiência fílmica e a angústia do sujeito contemporâneo, que evoca o conceito de adolescência.

Não é o fato de tratar-se de uma obra de ficção que nos impede de lançar um olhar crítico sobre o Clube da Luta. Em Moisés e o monoteismo (1996b), Freud é categórico ao considerar a narrativa bíblica uma "piedosa ficção imaginativa"; mas não deixa de considerá-la em seu exame das relações entre os fenômenos

\footnotetext{
Project Mayhem, no original, ou Projeto Desordem e Destruição, na tradução da Editora LeYa.

4 Poderíamos reconhecer, também, alguma proximidade com o estilo de certas montagens oníricas (à diferença que o narrador do Clube da Luta não sonha). "Quando se tem insônia, você nunca está acordado de verdade e nunca está dormindo de verdade."
} 
religiosos e os sintomas neuróticos. A ficção oferece à psicanálise um manancial inesgotável de inspiração, desde que devidamente situada; e, nesse caso, procurar categorias preestabelecidas para enquadrar um produto imaginado parece empobrecer o potencial que a obra nos oferece. Pois toda ficção, por mais fantasiosa que se proponha a ser, estará invariavelmente atravessada pela cultura onde ela é concebida. Zygmunt Bauman (2001) observa que as distopias imaginadas por Aldous Huxley, em Admirável mundo novo (de 1931), e George Orwell, em 1984 (escrito em 1948), não poderiam ser mais distintas; todavia ambas partilhavam um traço comum:

De modo semelhante a pensadores de outros tempos, Platão e Aristóteles, que não eram capazes de imaginar uma sociedade boa ou má sem escravos, Huxley e Orwell não podiam conceber uma sociedade, fosse ela feliz ou infeliz, sem administradores, projetistas e supervisores que em conjunto escreviam o roteiro que os outros deveriam seguir [...] (Bauman, 2001, p. 65).

Ou seja, consideramos a ficção potente na medida em que ela instaura uma descontinuidade em relação à realidade e, ao mesmo tempo, revela algo de sua estrutura; ou seja, uma função análoga a que Freud (1996c) atribuiu às piadas em Os chistes e sua relação com o inconsciente. Como assinala Fábio Herrmann (2006, p. 63), "Ficcional não significa falso, nem mesmo cientificamente menor, mas inserido num tipo de verdade peculiar à literatura". Não é necessário que a ficção apresente-se necessariamente como paródia ou crítica explícita, basta que se ponha a falar. Acompanhando Luciano Mattuela (2012), podemos admitir:

As produções culturais [...] são como os sonhos da Cultura: interpretam o recalcado de uma certa configuração social, explicitando através de uma forma mais ou menos metafórica os pontos de silêncio que dão coesão ao tecido simbólico de uma determinada época. (Mattuela, 2012).

E, de antemão, admitimos que Clube da Luta produz marca, ou seja, deixa um lastro singular em nossa cultura. Nem todas as produções conseguem tal êxito; de fato, a imensa maioria acaba por repetir um saber já evidente, perdendo-se nos discursos estabelecidos e, por fim, encorpando-os. Algumas poucas, contudo, preservam sua potência de interrogação, servindo-nos como importantes ferramentas de análise. Com efeito, a inscrição de Clube da Luta 
na cultura (e, em especial, no que se convencionou chamar de pop culture) 5 permite fazer dele um recorte para examinar aquilo que nela encontra-se recalcado.

\section{Clube da Luta e a adolescência}

Trabalhamos, pois, com a hipótese de que Clube da Luta traz à tona questóes sobre a adolescência, ou, melhor dizendo, sobre uma adolescentização do sujeito contemporâneo.

O leitor poderia objetar que, até onde se recorda, não há nenhum adolescente em cena durante todo o tempo de projeção, talvez não haja nem mesmo qualquer menção à adolescência, e teríamos de admitir que ele está correto. Como podemos nós, então, propor tal disparate?

Replicaríamos que a função da análise consiste precisamente em tecer linhas interpretativas que não estão dadas em um primeiro momento; ou, indo mais além, em construir uma nova ficção sobre a realidade do filme, como ensinam Vanoye e Goliot-Lété (2002). A associação de Clube da Luta à adolescência não está pré-colocada e provavelmente ultrapassa as intenções de Palahniuk e Fincher; ao ousar propor tal articulação, buscamos uma enunciação que faça jus à finalidade analítica de expansão de horizontes, não apenas visando uma nova possibilidade de leitura sobre a obra, mas também interpelando e ampliando o próprio corpo teórico da psicanálise.

Para montar com precisão a articulação entre Clube da Luta e adolescência, precisamos pontuar algumas chaves conceituais importantes. Em primeiro lugar, parece necessário recordar que, para a psicanálise, a adolescência situase como um tempo constitutivo do sujeito, ou seja, deve ser concedido a ela o estatuto de operação psíquica. Nessa operação, o que está em jogo é a saída de uma posição infantil, na qual o sujeito figura referido ao Outro primordial (e, eminentemente, como objeto no discurso do Outro), rumo a uma posição adulta, na qual poderá ser o agente de sua própria enunciação, ou, como lembra Giongo (2011, p. 18), "Construa um saber sobre o lugar que ocupa para o Outro". Isso tem duas consequências imediatas:

1) $\mathrm{O}$ descolamento entre as categorias de puberdade e adolescência. Enquanto a primeira designa um estágio biológico demarcado por certas

\footnotetext{
Poderíamos ilustrar essa afirmação, arrolando uma infinidade de referências a Clube da Luta encontradas no dia a dia, desde camisetas com as efígies de Edward Norton e Brad Pitt (devidamente machucados) circulando em Barcelona a pichações em muros de Kandahar, com as palavras de ordem do Projeto Destruição, além de um sem-número de menções em filmes posteriores. Elas perduram, mais de uma década após a popularização do filme; outras obras desapareceram muito antes disso. Deixamos como indicação a leitura do posfácio redigido por Palahniuk; ele mesmo se ocupa de ponderar sobre os efeitos de sua obra. Sem grandes ilusões, aliás. Os garçons continuarão mijando na sopa.
} 
mudanças orgânicas, com ênfase na maturação genital, a segunda se refere a uma determinada posição do sujeito em relação à linguagem.

2) A passagem pelos tempos estruturantes da infância opera como condição sine qua non para o advento da adolescência. Ainda que dessa passagem resultem fraturas, falhas na inscrição de significantes preciosos, é imprescindível uma travessia desses tempos de separação do Outro para que se possa falar em adolescência.

A conjunção das duas proposições acima condiz com aquilo que testemunhamos diariamente na prática clínica. Encontramos indivíduos de 15, 17, 19 anos que não experienciaram (e talvez jamais experienciem) qualquer coisa minimamente próxima ao que entendemos por adolescência, por causa de psicopatologias que os aprisionam em tempos muito primitivos da infância. Por outro lado, testemunhamos crianças precocemente introduzidas na adolescência antes mesmo que seus corpos possam demonstrar as correspondências biológicas esperadas, e, de outra parte, sujeitos que prolongam indefinidamente um tempo dito "de passagem", vivenciando por décadas uma transição que nunca chega a termo. Assim, embora o termo "adolescente" designe certo tipo de indivíduo, o fenômeno "adolescência" atravessa a sociedade de um modo muito mais abrangente. Como assinala Calligaris (2011, p. 57), a adolescência desponta como um ideal social, e pondera: "É até bem possível que a adolescência surja na modernidade como um ideal necessário".

Ocorre que, na sociedade contemporânea, a adolescência é uma construção potente e paradoxal: ao mesmo tempo em que aparece investida de atributos fascinantes, encarnando imaginariamente o "sonho de idiossincrasia, de unicidade, de liberdade individual e de desobediência [que] é próprio de nossa cultura”, conforme assinala Calligaris (2011, p. 59), ela também é colocada à margem do mundo adulto. Retomamos o conceito de moratória introduzido por Erik Erikson6 para problematizar o lugar em que a adolescência é colocada. $\mathrm{O}$ avanço da modernidade e as mudanças nos processos de subjetivação que o acompanham levam em seu bojo a queda dos ritos de passagem que determinariam $\mathrm{o}$ ingresso dos sujeitos em um universo adulto. Sem tais referenciais, o universo adulto converte-se em um clube exclusivo com regras de ingresso incertas, deixando o tempo de concluir a adolescência em uma suspensão indefinida,

\footnotetext{
6 Ainda que a noção de um tempo de não protagonismo social tenha sido enunciada anteriormente por outros autores, Erikson condensa, em sua obra, a mais proeminente expressão dessa perspectiva. Todavia, embora Erikson pontue a moratória social da adolescência como um lapso temporal no qual o sujeito poderia experimentar, ensaiar e errar, o comentário de Luís Antônio Groppo, com base na leitura de Kruskopf permitirá compreender essa condição menos como uma construção de sabedoria social e mais como uma postergação das possibilidades efetivas de participação (Groppo, 2009).
} 
portanto angustiante. A contraface da idealização da adolescência é a angústia (e é esse o nervo pinçado por Clube da Luta).

Lembramos que o começo da história, em termos cronológicos, reside na insônia do narrador, que recorre a um médico para sanar sua agonia. Seu pedido de ajuda, como sói ocorrer no cotidiano clínico, antecipa uma solução farmacológica, que, todavia, é negada. $\mathrm{O}$ médico sugere que o narrador visite grupos de ajuda para conhecer, aí sim, o sofrimento de verdade. Seguindo esse conselho, o narrador se torna um frequentador assíduo dos mais diversos grupos de apoio: parasitas do sangue, câncer testicular, demência. Em um desses encontros, ele conhecerá Marla Singer.

Aqui traçamos o primeiro paralelo entre Clube da Luta e a adolescência. Amadeu Weinmann (2012) observa que a adolescência figura como uma experiência que flerta com a morte, mesmo que seja para suportar a vida, como se a iminência do encontro final com a castração pudesse conferir uma significação definitiva para um desamparo avassalador. E a questão da morte atravessa diametralmente a narrativa de Clube da Luta: "Essa é sua vida, e ela está acabando a cada minuto". O emprego do narrador envolve avaliar se, para sua companhia, é menos oneroso realizar recalls de peças defeituosas ou pagar as despesas de acordos judiciais com as vítimas. Explica o narrador:

Eu era o coordenador do recall, e meu trabalho era aplicar a fórmula. Um carro novo da minha companhia parte de algum lugar viajando a 60 milhas por hora. $O$ diferencial traseiro se trava. $O$ carro bate $e$ incinera com todos presos do lado de dentro. Então, devemos iniciar um recall? Pegue o número de carros no mercado, A. Multiplique pela taxa provável de falhas, B. Multiplique o produto pelo valor médio dos acordos extrajudiciais, $C . A \times B \times C$ é igual a $X$. Se $X$ for menor que o custo do recall, nós não fazemos.

Fincher não é econômico ao filmar Edward Norton conferindo vestígios humanos dentro de um carro carbonizado, incluindo os comentários. $\mathrm{Na}$ mesma tônica, a saída para sua insônia reside no tempo compartilhado com portadores de doenças terminais. "Ao caminhar para casa depois de ir a um grupo de apoio, eu me sentia mais vivo do que nunca". Mais adiante, uma das lições de casa dos membros do clube da luta envolve um sacrifício humano - executado em memorável episódio, no qual Raymond K. Hessel (Joon B. Kim), empregado no Korner Mart, é convidado a reconsiderar sua vida sob a mira de uma arma (que, não por acaso, guarda semelhanças com a cena inicial entre Tyler e o narrador). Marla é salva por Tyler de uma tentativa desastrada de suicídio mediante Xanax. Bob (Meat Loaf) é morto por policiais e velado na companhia de sabão da Paper Street. Chloe (Rachel Singer), 
integrante de um dos grupos de apoio, eventualmente vem a falecer. No livro, o plano original de Tyler Durden consiste em explodir junto com os prédios, convertendo-se em mártir de sua causa. $\mathrm{O}$ enredo literário ainda contempla dois homicídios perpetrados por Tyler, os quais se encontram ausentes na versão fílmica: o assassinato de Patrick Madden, secretário municipal contrário aos clubes da luta, durante uma festa temática (que foi condensado em outra passagem radicalmente suavizada), e o explosivo artesanal que tira a vida do chefe do narrador (essa, sumariamente excluída). Em quase todos os momentos de Clube da Luta, existe algum tipo de alusão, mais ou menos direta, à morte, com exceção, talvez, das lutas propriamente ditas.

Afirmamos anteriormente que não vemos adolescentes em cena; Clube da Luta é povoado inteiramente por adultos. Há uma ou duas referências laterais à infância dos protagonistas, e o livro ainda traz uma menção à juventude. Na tela, vemos adultos (homens, em sua grande maioria) que, apesar de todas as diferenças, partilham um mesmo sofrimento: a angústia de habitar um não lugar. "Nós somos os filhos do meio de Deus", são as palavras de Tyler, "e não temos lugar especial na história nem atenção". Ele vai mais fundo: "Não temos uma grande guerra em nossa geração ou uma grande depressão, mas na verdade temos, sim, uma grande guerra espiritual". Tyler faz as vezes de porta-voz de uma geração fadada a ser esquecida, a não deixar rastro, a não imprimir qualquer marca simbólica singular; em outras palavras, uma geração aprisionada na posição de objeto.

A significação da morte em Clube da Luta está longe de ser unívoca. Existem assassinatos, existem doentes terminais, existem experiências limítrofes de quase morte (ou quase vida, como salientam os membros do Projeto Destruição). "Em uma linha do tempo longa o suficiente, a taxa de sobrevivência de todo mundo cai para zero." A morte é uma personagem constante. Mas, nessa morte, o corpo que se pretende deixar para trás tem especificidades. É o corpo gozado, porém restringido em seu gozar; o corpo imaculado da infância, que idilicamente atravessa a existência sem produzir nenhuma cicatriz; enfim, o corpo dócil. Como assinala Weinmann, o que está em questão na adolescência é a morte do corpo infantil:

Este é o drama da passagem adolescente. Decifra-me ou te devoro. Simboliza esse real - no limite, uma missão impossível, pois o real é justamente o que resiste a inscrever-se - ou te entrega a uma das muitas faces da morte. (Weinmann, 2012, p. 383). 


\section{Os objetos e o resto}

A ruptura com o corpo infantil parece não conhecer alternativa, senão por meio da brutalidade. Se a contraparte da idealização de uma adolescência maravilhosa é a angústia por habitar um não lugar, a imagem do adolescente transgressor, potente e desejável conhece seu reverso na multidão anônima a qual o discurso iconoclasta de Tyler enlaça:

Eu vejo, no clube da luta, os homens mais fortes e inteligentes que já existiram. Eu vejo todo esse potencial e o vejo desperdiçado. Por Deus, uma geração inteira abastecendo carros, servindo mesas; escravos de uniforme. A propaganda nos faz almejar carros e roupas, trabalhar em empregos que odiamos para poder comprar porcarias que não precisamos (Fincher, 1999).

Uma fala poderosa: de fato, nossa cultura alimenta a ilusão de que, por meio dos bens de consumo (seja uma televisão com 500 canais ou o nome de um estilista famoso bordado em nossas cuecas), seria possível superar a divisão estrutural do sujeito e, quem sabe, aceder ao lugar de cidadão pleno na sociedade. Ocorre, todavia, que tal cisão não é solucionável, e o consumo sequer se mostra libertador: "na verdade", diz Paulo Endo,

Os adolescentes estão sendo deixados à beira do caminho pelos interesses mercantis do mundo adulto para se alimentar do lixo cultural que, resignadamente, consomem sem parar (drogas, grifes, baladas, mundo eletrônico e virtual, imagens pornográficas, imagens violentas). (Endo, 2009, p. 58).

Denise Hausen (2012) retoma a cena em que o narrador folheia um encarte publicitário, ponderando que as revistas pornográficas foram substituídas pelos catálogos de móveis da IKEA; no filme, isso ocorre com Edward Norton sentado no vaso sanitário, permitindo à autora a associação entre o ato de comprar e o ato de evacuar: "sentado na patente, seu pensamento não fantasia, faz compras", assinala Hausen (2012, p. 216). A autora ressalta a facilidade da substituição dos objetos na economia do gozo, tendo em vista a promessa publicitária de um acesso imediato aos produtos fetichizados. A cena, contudo, guarda ainda outra interpretação possível: que, no ato da compra, tal qual no ato da evacuação, aquilo que cai é o sujeito. Sabemos que o dejeto não constitui uma sobra na relação de objeto, senão que é uma face do próprio objeto.

A cisão entre os objetos fetichizados do consumo e os sujeitos que os desejam, situados como resto, é radicalizada no discurso de Tyler: "Você não é seu trabalho. Você não éo dinheiro que tem no banco. Você não é o carro que dirige. Você é a merda do 
mundo". ${ }^{7}$ Não é somente um dedo na ferida da cultura capitalista, é uma queimadura química oriunda dos lábios de Tyler. "Vocês não são especiais. Vocês não são um grão de neve belo e único. Vocês são a mesma matéria orgânica em decomposição, assim como todo o resto". As palavras de ordem dos clubes da luta não ressaltam apenas a condição de resto, mas atacam especialmente a promessa de singularidade. Como lembra Calligaris (2011), a sociedade contemporânea exalta os valores da individualidade e da independência; testemunhamos, contudo, uma impregnação de estratégias de massificação que tornam esses valores uma busca virtualmente impossível. $\mathrm{O}$ embotamento da singularidade será repetido, como farsa, pelos "macacos espaciais" do Projeto Destruição, mas, antes disso, ele toma contornos no ponto em que o humano conhece seu traço mais íntimo: a nomeação.

Começamos pelo protagonista. Em nenhum momento do livro ou do filme, a personagem de Edward Norton é efetivamente nomeada. No filme, pode-se ler nos crachás utilizados pelo narrador nos grupos de apoio nomes como Travis, Rupert e Cornelius (pseudônimos escolhidos por Fincher como homenagem a clássicos do cinema). ${ }^{8}$ Alguns escritos optam por se referir a ele como Jack, baseando-se em uma frase de efeito usada ao longo da trama, mas fica razoavelmente claro que esse nome é retirado de uma revista encontrada pela personagem. Curiosamente, essa fora a designação utilizada durante a produção do filme, bem como em alguns materiais de divulgação. É ainda mais interessante observar que a frase de onde deriva essa nomeação ("I am Jack's colon", "Eu sou o cólon de Jack") e que serve de matriz para as demais ("I am Jack's complete lack of surprise", "I am Jack's inflamed sense of rejection", "I am Jack's wasted life"), consta, no livro, como "I am Joe's prostate", o que não apenas denuncia uma alteração importante na transição das páginas para a película, mas, de certa forma, deixa também incerta a validade da utilização do nome "Jack" para assinalar o narrador. Por fim, apesar da revelação derradeira, supor que Tyler Durden é o nome verdadeiro do narrador também não conduz a uma opção acertada. O fato de Marla e dos outros membros do Projeto Destruição identificarem o narrador por tal designação não implica que ele mesmo se reconheça sob esse nome; o que, aliás, não ocorre: no livro, Palahniuk deixa explícito que esse é mais um dos nomes inventados pelo narrador, e não coincide com aquele que consta de sua carteira de motorista; Fincher conduz essa separação de uma maneira mais sutil, mas preserva a distinção entre o narrador não nomeado e seu duplo, Tyler

\footnotetext{
A citação, conforme consta do filme, figura da seguinte forma: "You're not your job. You're not how much money you have in the bank. You're not the car you drive. You're not the contents of your wallet. You're not your fucking khakis. You're the all-singing, all-dancing crap of the world". O khakis mencionado por Tyler se refere às calças cáqui, tipicamente usadas por funcionários de algumas lojas de departamento norte-americanas; já a expressão all-singing, all-dancing, derivada das propagandas de musicais da Broadway, remete à ideia de vitalidade, jovialidade, excitação. Infelizmente, a tradução não logra êxito em transmitir a ironia e a acidez presentes nesse trecho.

8 Segundo o site IMDb, Cornelius faz alusão à personagem de Roddy McDowall em Planeta dos Macacos; já Rupert e Travis remetem a interpretaçôes de Robert DeNiro em O Rei da Comédia e Taxi Driver, respectivamente.
} 
Durden.

Entretanto a experiência da morte parece permitir o advento de um nome próprio. Todas as personagens nomeadas, sejam principais ou secundárias, encontram a morte de alguma maneira. Três casos são especialmente destacáveis: Marla Singer, Raymond K. Hessel e Bob. Como mencionamos anteriormente, Marla tangencia a morte contemplando o suicídio, sendo resgatada de sua tentativa desastrada (ou não?) por Tyler Durden. Passemos então aos dois eventos seguintes.

O primeiro é abordado na saída do trabalho como parte de um "sacrifício humano". Com uma arma mirada para sua cabeça, tem a carteira e a vida revistadas. Seu apartamento pequeno. Seu trabalho medíocre. Suas escolhas abandonadas. "Raymond, você vai morrer. O que você queria ser, Raymond K. Hessel?". Raymond queria ser veterinário. A carteira de motorista em que consta de seu endereço é apropriada pelo Projeto Destruição. Prometem que ele será vigiado; caso não retome os estudos, morrerá. Permitem, então, que ele vá embora, aterrorizado. "Amanhã será o dia mais bonito da vida de Raymond K. Hessel', responde Tyler.

No polo oposto, vemos Bob. Bob tem tetas de mulher, efeito colateral da terapia hormonal à qual se submeteu após ter seus testículos removidos. $\mathrm{O}$ narrador conhecera Bob em um dos grupos de apoio; posteriormente, Bob retornaria como voluntário do Projeto Destruição. Em uma das missões, contudo, Bob é baleado, e seu corpo levado até a companhia de sabão da Paper Street. No filme, o narrador, atônito ao ver seu amigo dentro de um saco plástico, tenta impedir que Bob seja enterrado no quintal da casa da Paper Street, evocando seu nome completo, Robert Paulson. "Apenas na morte merecemos nosso nome verdadeiro", entendem os macacos espaciais.

Admitimos, anteriormente, que o trânsito da adolescência se marca pela morte do corpo infantil e pela possibilidade de uma enunciação própria. Essa enunciação requer a demarcação de um lugar específico desde onde possa se efetuar, exige a construção de um lugar no Outro. Em Clube da Luta, a morte e a nomeação são emparelhadas. A morte concreta, deslocada de seu registro simbólico, permite o acesso a um nome próprio; mas ela exige ser visualizada, tocada, experimentada até o limite e eventualmente atravessada. Afirmamos anteriormente que, embora a temática da morte atravesse toda a trama de Clube da Luta, nas lutas propriamente ditas, ela talvez esteja ausente. Alternativamente, o centro do clube da luta permite outra morte, que não o óbito real: a morte do corpo infantil, a qual também requer um sacrifício de sangue, mas alça os sujeitos a uma posição de autoria, ainda que somente pela duração do combate. "Esse garoto do trabalho, Ricky, não conseguia nem 
lembrar se lhe pediam caneta azul ou preta. Mas Ricky foi um deus por dez minutos enquanto surrava o maitre de um restaurante local'.

\section{Experiência e silêncio}

Palahniuk relata, no posfácio de seu livro, que a inspiração para redigir Clube da Luta partiu de uma vivência pessoal: trazia ele, como lembrança de uma briga nas férias, um olho roxo que custava a sarar e, no entanto, nenhum de seus colegas de trabalho formulara qualquer questão sobre o óbvio ferimento. Era como se não existisse, nem o olho roxo, nem a experiência que o poderia ter causado. É possível supor que o silêncio, acordado tacitamente entre as testemunhas involuntárias, serviu de base para a mais célebre frase de Tyler: "Você não fala sobre o clube da luta".

Voltemos à adolescência, por um instante, tomando como guia as palavras de Calligaris:

Recusado como par pela comunidade dos adultos, indignado com a moratória que lhe é imposta e acuado pela indefinição dos requisitos para terminá-la (a famosa e enigmática maturidade), o adolescente se afasta dos adultos e cria, inventa e integra microssociedades. (Calligaris, 2011, P. 36).

O fenômeno gregário desponta como saída para o desamparo incutido na posição de resto. Entretanto, no caso dos clubes da luta, podemos inferir que não se trata apenas da obturação da angústia mediante rituais miméticos; talvez o que esteja em jogo, fundamentalmente, seja a inscrição em nível corporal de algo da ordem da experiência, utilizando a concepção de Walter Benjamin (2010). Isso porque, diante do apagamento radical de singularidade a que a cultura contemporânea induz seus sujeitos, o corpo se torna um refúgio último para a possibilidade de autoria da própria vida: "Na adolescência há um segundo tempo de separação [do Outro], o que implica também criação. Criar é refazer o fantasma, buscar novos cenários para que esse novo corpo ganhe sentido e lugar", assinala Ângela Becker (2008, p. 150). E vai além, pontuando que "criar é reescrever o corpo de modo que possa ser reinscrito" (Becker, 2008, p. 150). Mas existem lugares legitimados para essa criação, senão em retorno ao próprio corpo?

Tomemos em perspectiva, finalmente, a invenção dos clubes da luta, baseados em poucas regras, ${ }^{9}$ enunciadas aos brados na abertura de cada encontro. Não deixa de ser intrigante notar como a estrutura do regimento interno estabelece, ao

\footnotetext{
A saber: 1) você não fala sobre o clube da luta; 2) você não fala sobre o clube da luta; 3) quando alguém diz "pare" ou fica desacordado, a luta acaba; 4) apenas duas pessoas por luta; 5) apenas uma luta por vez; 6) sem camisas ou sapatos; 7) as lutas duram o quanto tiverem que durar; e 8) se essa for sua primeira noite no clube da luta, você precisa lutar.
} 
mesmo tempo, um código de pertença e uma sátira à organização social. Se a comunidade humana não encontra lugar para esses sujeitos, a vida marginal nos porôes dos bares os acolhe de braços abertos. Da mesma forma, se a adolescência não localiza marcas que balizem o ingresso no mundo adulto, os grupos de semelhantes inventarão seus próprios ritos; nesse caso, legando ao iniciado uma senha evidente na forma de hematomas, supercílios cortados e dentes partidos.

O estatuto de sátira contido nas regras não tarda a se revelar. " $A$ primeira regra do clube da luta é que você não fala sobre o clube da luta. A segunda regra do clube da luta é que você não fala sobre o clube da luta." O pacto de sigilo, estabelecido na primeira regra e enfatizado pela segunda, não vinga; Tyler, observando a presença de novos rostos no clube, explicita a quebra das primeiras regras. Entretanto, a última regra ("Se essa for sua primeira noite no clube da luta, você deve lutar") prevê o rito de iniciação dos ingressantes, assumindo, assim, que o silêncio sobre a existência dos clubes da luta seria invariavelmente desrespeitado. Aliás, o crescimento exponencial de membros sugere que as duas regras fundamentais do clube da luta jamais foram obedecidas. A contradição interna do regimento nos leva a concluir que seu propósito não é exatamente o de ordenar o funcionamento dos clubes, mas de satirizar a ordenação social. "Sem sapatos nem camisas" deixa de fora do clube a indumentária típica do universo do trabalho (e particularmente do trabalho burocrático, correspondente atual das velhas engrenagens fabris); "Apenas dois homens por luta, apenas uma luta por vez" reflete as condiçôes de manutenção do frágil equilíbrio entre Tyler e o narrador, vetando a interferência de Marla - ou de qualquer agente que, como terceiro, possa colocar a bizarra (des)harmonia dos protagonistas em questão. Mais adiante, os próprios questionamentos serão negados, sob forma de uma nova regra: "Você não faz perguntas sobre o Projeto Destruição". No filme, as regras do clube da luta são enumeradas uma a uma por Tyler; no livro, contudo, apenas as duas primeiras regras recebem uma numeração e, curiosamente, a última regra ("Se essa for sua primeira noite...") é dita como sétima. Se descartarmos a hipótese de tratar-se de um lapso de Palahniuk corrigido por Fincher, ou de uma severa inaptidão à matemática de Tyler, podemos aceitar que as regras 4 e 5 constituem um mesmo item, interpretação que a redação do livro permite, se considerada a forma de pontuação. Todavia, ampliando nossa interpretação, perceberemos que uma mesma confusão quanto à distribuição numérica acomete os Dez Mandamentos do texto bíblico, de forma que cada vertente religiosa (judaísmo, catolicismo, cristianismo ortodoxo, protestantismo, etc.) observa uma divisão específica do cânone. 
Torna-se ainda difícil desprezar completamente tal hipótese (bem como a compreensão das regras do clube da luta como sátira) se considerarmos as referências diretas à religião distribuídas por toda a obra (em especial, ao abandono que Deus, como pai, impôs aos seus filhos) e à percepção do narrador de que no clube da luta "há gritos histéricos como em uma igreja, $e$, ao acordar no domingo à tarde, você se sente salvo".

Como lembra Calligaris (2011), a adolescência também é pródiga na criação de coletivos extravagantes, especialmente quando se trata de parodiar a comunidade adulta. Poderíamos ler esse fenômeno como efeito direto do que chamamos de moratória que, mais do que a simples não aceitação do adolescente como igual entre os adultos, deve ser compreendida como um profundo sentimento de desfiliação. A fundação de microssociedades, com senhas e legislações próprias (que frequentemente espelham e distorcem aquelas encontradas na vida cotidiana), coloca em evidência um angustiante desencontro entre o sujeito e a cultura na qual ele se insere. Em tempos idos, pontuava-se a entrada no mundo do trabalho como possibilidade de resolução da adolescência e de colocar-se em termos razoáveis com o social; ora, os frequentadores dos clubes da luta têm profissóes estabelecidas: garçons, motoristas, representantes de vendas, executivos. Em Mal-estar na civilização, Freud (1996a, p. 88) ressaltou a possibilidade de, por meio da ênfase no trabalho, receber o sujeito um "lugar seguro numa parte da realidade, na comunidade humana". Todavia, como mui apropriadamente recorda Bauman (2001), assim como a Modernidade do início do século XX não é igual à Modernidade da virada do milênio, o homem referido por Freud não é o mesmo homem que devora (e é devorado) pelos gadgets contemporâneos; logo, as saídas que servem a um não necessariamente operarão ao outro. Em Clube da Luta, inscrito no último caso, o trabalho é representado majoritariamente em sua faceta de assujeitamento, imposto a indivíduos que não conseguem extrair dele um sentido para suas existências. Na verdade, ele se converte em mais um elemento de uma série virtualmente infinita de bastióes caídos, ao lado da faculdade e do casamento:

Meu pai não foi à faculdade, então era importante que eu fosse. [...] Então eu me formei, liguei pro meu pai e perguntei: pai, e agora? Ele disse: arranje um trabalho. [...] Aí eu tenho 25 anos e, quando faço minha chamada anual de novo, digo: pai, e agora? Ele diz: eu não sei, case.

Diante da confidência de Tyler, o narrador objeta: "Não se pode casar assim. Eu sou um garoto de 30 anos". 


\section{Momento de concluir}

Ao longo de nosso ensaio, tomamos Clube da Luta como interlocutor para problematizar a angústia adolescente, marcada pela habitação de um lugar eminentemente marginal dentro de um enlace social que, ao mesmo tempo em que louva os valores de autonomia e independência, aprisiona seus sujeitos em uma moratória de duração indefinida. A promessa de liberdade e opulência cede lugar à desilusão de uma existência empobrecida; empobrecimento não apenas no âmbito material, ao qual o consumo voraz tenta suprir, mas especialmente na esfera das experiências. $\mathrm{Na}$ tela, Tyler apresenta-se como porta-voz dessa frustração: "Nós fomos criados pela televisão acreditando que, um dia, seríamos milionários, e deuses do cinema, e astros do rock. Mas não seremos, e lentamente estamos compreendendo esse fato. E nós estamos muito putos com isso". Todavia, como assinalamos, o filme não exibe adolescentes, mas predominantemente homens adultos. Talvez considerássemos esse detalhe uma mera opção estética do diretor, não fosse o fato de que ele enuncia um elemento importante para a leitura da cultura: a expansão da condição adolescente, cujos tentáculos gradualmente apossaram-se dos territórios contíguos da infância e da vida adulta. Parece cada vez menos crível conceber a adolescência simplesmente como etapa intermediária no ciclo vital; como assinala Paulo Endo (2009, p. 89), "A adolescência não é um lugar estanque, uma espécie de hiância entre o não mais e o não ainda, ela se inscreve no mesmo fluxo de injunçōes políticas, sociais e psíquicas que acompanham a vida dos seres humanos em sociedade". Podemos supor que a marca deixada por Clube da Luta em nossa cultura ganha relevo precisamente na medida em que expressa a adolescentização do sujeito contemporâneo, desvelando a agonia de sentir-se incapaz de cumprir o ideal que lhe fora outorgado e emudecido na posição de resto. De certa forma, é como se o tempo de enunciar-se (ou seja, de inscrever-se na comunidade humana por meio de um ato singular, autoral) fosse sistematicamente postergado pelas condições de pertença da própria cultura. O desfecho escrito por Palahniuk difere daquele sugerido por Fincher: neste, o narrador contempla a explosão de locais-chave da organização financeira; naquele, tendo falhado sua nitroglicerina, acaba em uma clínica, reconhecendo nos enfermeiros as inconfundíveis lesões e hematomas. "Esperamos ansiosos pela sua volta", sussurra um servente de nariz quebrado. O filme altera essa conclusão, deixando-nos, junto ao narrador, com a vista da devastação dos pilares da civilização. É interessante o deslocamento proposto por Fincher, já que, no livro de Palahniuk, o alvo original de Tyler é o museu nacional situado ao lado do Edifício Parker-Morris. A substituição, contudo, é potente, pois devolve ao espectador contemporâneo, tocado pelo mote que 
permeia a trama de Clube da Luta (a perspectiva de não possuir lugar para si na história), a mesma pergunta lançada por Tyler Durden, imerso na banheira e recordando a ausência de referências para ordenar sua vida, representada na voz paterna: e agora?

\section{Referências}

Arós, A. C. S. P. C. \& Vaisberg, T. M. J. A. (2009). Clube da luta: sofrimentos radicais e sociedade contemporânea. Psicologia: Teoria e Prática, 11 (2), 3-16.

Bauman, Z. (2001). Modernidade líquida. Rio de Janeiro: Jorge Zahar.

Becker, A. L. (2008, julho/dezembro). A angústia da dança adolescente. Revista da Associação Psicanalítica de Porto Alegre, 35, 149-156.

Benjamin, W. (2010). Magia e técnica, arte e politica: ensaios sobre literatura e história da cultura. São Paulo: Brasiliense.

Calligaris, C. (2011). A adolescência. São Paulo: Publifolha.

Endo, P. (2009). O adolescente: figura ilustre do contemporâneo. Estilos da Clinica, 14 (27), 82-91.

Fantini, J. (2009, novembro). O eterno retorno da lei: busca e derrisão da figura paterna em Matrix e Clube da Luta. Leitura Flutuante - Revista do Centro de Estudos em Semiótica e Psicanálise. Recuperado em 27 de setembro de 2012, de http://revistas.pucsp.br/index.php/leituraflutuante/article/ view/7625.

Fincher, D. (Diretor). (1999). Clube da Luta [DVD]. São Paulo: Fox Filmes.

Freud, S. (1996a). Mal-estar na civilização. In S. Freud. Edição standard brasileira das obras psicológicas completas de Sigmund Freud (Jayme Salomão, Trad., Vol. 21, pp. 67-148). Rio de Janeiro: Imago. (Texto original publicado em 1930.)

Freud, S. (1996b). Moisés e o monoteísmo. In S. Freud. Edição standard brasileira das obras psicológicas completas de Sigmund Freud (Jayme Salomão, Trad., Vol. 23, pp. 15-150). Rio de Janeiro: Imago. (Texto original publicado em 1937.) 
Freud, S. (1996c). Os chistes e sua relação com o inconsciente. In S. Freud. Edição standard brasileira das obras psicológicas completas de Sigmund Freud (Jayme Salomão, Trad., Vol. 8, pp. 11-227). Rio de Janeiro: Imago. (Texto original publicado em 1905.)

Giongo, A. L. (2011, maio). Da latência à adolescência: impasses diante do infantil. Correio da APPOA, 201, 15-23.

Groppo, L. A. (2009). O funcionalismo e a tese da moratória social na análise das rebeldias juvenis. Estudos de Sociologia, 14 (26), 37-50.

Hausen, D. C. (2012). Cinema e psicanálise: o conceito de castração em transversal. Porto Alegre: Movimento.

Herrmann, F. (2006, junho). Psicanálise, ciência e ficção. Jornal de Psicanálise, 39 (70), 55-79.

Mattuela, L. (2012). "Todos são felizes agora”: a ficção literária como interpretação da Cultura. Texto não publicado.

Minerbo, M., Silveira C. S. B., Antila, C. C. P. G., Celeri, E. H. R. V., Penna, E., Herrera, F. B. G. et al. (2006, junho). O Clube da Luta: narcisismo, identificação e psicologia das massas. Jornal de Psicanálise, 39 (70), 149-161.

Palahniuk, C. (2012). Clube da luta. (Cassius Medauar, Trad.). São Paulo: LeYa.

Souza, E. (2011). O trânsito entre o cinema e a psicanálise. In E. Souza \& R. F. Pereira. Cinema: o divã e a tela. (pp. 12-18). Porto Alegre: Artes e Ofícios.

Vanoye, F. \& Goliot-Lété, A. (2002). Ensaio sobre a análise fílmica. Campinas: Papirus.

Weinmann, A. O. (2012). Juventude transgressiva: sobre o advento da adolescência. Psicologia \& Sociedade, 24 (2), 382-390. 